Article

\title{
Assessing the Biostimulant Effects of a Novel Plant-Based Formulation on Tomato Crop
}

\author{
Antonios Chrysargyris, Savvas Charalambous, Panayiota Xylia, Vassilis Litskas, \\ Menelaos Stavrinides $(D)$ and Nikos Tzortzakis * (iD
}

Department of Agricultural Sciences, Biotechnology and Food Science, Cyprus University of Technology, Limassol 3036, Cyprus; a.chrysargyris@cut.ac.cy (A.C.); tsiarloui22@gmail.com (S.C.); pa.xylia@edu.cut.ac.cy (P.X.); vassilios.litskas@cut.ac.cy (V.L.); m.stavrinides@cut.ac.cy (M.S.)

* Correspondence: nikolaos.tzortzakis@cut.ac.cy; Tel.: +357-2500-2280

Received: 18 September 2020; Accepted: 7 October 2020; Published: 13 October 2020

\begin{abstract}
The aim of this research was to evaluate the biostimulant effects of an eco-product (EP) containing essential oils of rosemary and eucalyptus on tomato crop. Experiments were conducted to evaluate EP effects on plant growth and physiological parameters (e.g., chlorophyll content), total phenols and antioxidant activity, enzyme activities (e.g., catalase), plant macronutrient content and fresh tomato fruit quality. The application of an EP once (EP-1x) increased tomato plant height by $19 \%$, stomatal conductance, and chlorophyll content compared to the control (sprayed with water). EP triplicate (EP-3x) application significantly increased yield $\left(0.79 \mathrm{~kg} \mathrm{plant}^{-1}\right)$ compared to the control $\left(0.58 \mathrm{~kg} \mathrm{plant}^{-1}\right)$. However, application of EP-3x was associated with a higher percentage of fruit cracking in comparison to the control. Total phenols and antioxidant activity were affected from both the use of EP and application frequency. EP application decreased by $27.3 \%$ the leaf damage index in comparison to the control. Nutrient content in leaves $(\mathrm{N}, \mathrm{Mg})$ was significantly decreased in the case of EP-3x treatment. Fruit firmness was decreased by 19.9\% in the case of EP-1x application. Fruit marketability and tomato-like aroma, fresh weight and soluble solids did not differ among the treatments. Further research is required to examine the potential use of essential oils as biostimulants.
\end{abstract}

Keywords: essential oils; rosemary; eucalyptus; biostimulants; vegetable production; fruit quality

\section{Introduction}

A main issue for humanity is global food security, as demographic projections place the human population size at 9.5 billion by 2050. Securing and maximizing crop production under the threat of climatic change is a major challenge for the agricultural sector [1]. Research towards securing food production is focusing, in part, on the use of biostimulants to support agricultural production [2-4]. The term biostimulant refers to a broad range of substances and/or microorganisms used in agriculture to enhance soil fertility, plant tolerance to stress, plant growth, productivity and produce quality crops [2,5-7].

Biostimulants based on amino acids and marine algae have been applied in horticulture for many years [8]. Such materials are typically a rich source of phytohormones (e.g., auxins, cytokinins, gibberelins, abscisic acid) and polyphenol compounds [7,9]. More recently, substances such as humic and fulvic acids, protein hydrolysate and silicon have been tested with promising results to increase yield under normal conditions or maintain it under unfavorable conditions [1,10]. Moreover, the use of arbuscular mycorrhizal fungi (AMF), Trichoderma spp. and plant growth promoting rhizobacteria could support food production, especially in low input agriculture (e.g., reduce $\mathrm{N}$ and $\mathrm{P}$ fertilizers application) [5,11]. Low input agriculture supports climate change mitigation [12] and biostimulants application could support this goal $[9,13]$. 
Several research papers have demonstrated the positive effects of biostimulants use in vegetables and fruits. For instance, marine algae (Ascophyllum nodosum)-based products have been tested in lettuce and this resulted in increased yield [14] and alleviated the detrimental effects of potassium deficiency during plant growth and storage of processed products [15]. Biostimulants were also studied for their effects on water-stressed plants $[9,16]$. The results of Pereira et al. [16] highlighted the importance of using biostimulants in arid environments to increase plant yield and nutrients content. Under soil salinity conditions, root and leaf-root application of plant-derived protein hydrolysates increased fresh yield, dry biomass and root dry weight of lettuce [1]. Biostimulant application increased the phenolic antioxidants in broccoli heads and spinach $[8,17]$. In contrast, four biostimulant products (Megafol, Aminovert, Veramin, Twin Antistress) did not demonstrate any promising results concerning their ability to increase the content of phenolic antioxidants in two spinach varieties under water stress [16]. Soaking of bean seeds or foliar sprays with salicylic acid (SA) or Moringa oleifera leaf extract increased the nutrient content (N, P, K, Ca) of bean leaves [18]. In addition, concentrations of total chlorophylls, total carotenoids, total soluble sugars, free proline and ascorbic acid, were higher for treated bean plants compared to the tap water control. Biostimulants have been tested to evaluate their impact in enhancing tolerance to drought [19], enhancing yield and nutritional quality [20,21], preventing yield loss and oxidative stress [22]. Arbuscular mycorrhizae fungi and seaweed extract have been mainly tested in such experiments with tomato [23].

Even if there is currently a plethora of published papers on the use and effects of biostimulants, mainly on vegetables and fruits, the potential use of essential oils as biostimulants has received less attention. Rosemary (Rosmarinus officinalis L.) essential oil has been applied on tomato seedlings with beneficial effects on nutrient uptake and better plant growth [24]. Essential oils contain many organic substances that could possibly act as biostimulants, similar to what has already been observed for organic matter-related substances [25]. In addition, in contrast to the majority of papers related to biostimulant effects, which focus on the effects of biostimulants on plant growth and product yield/quality, less is known about their impact on enzymatic activities.

Essential oils from rosemary (R. officinalis L.) and eucalyptus (Eucalyptus globulus L.) are rich in 1,8-cineole (commonly known as eucalyptol) with diverse biocidal activities, such as insecticidal [26], antibacterial [27,28], herbicidal [29], antifungal [30], antiallergic, antitumoral and gastroprotective action as reviewed by Caldas et al. [31]. The aim of this research was to evaluate the biostimulant effects of an eco-product (containing essential oils of rosemary and eucalyptus) on tomato crop. More specifically its effects were evaluated on: (1) plant growth and physiological parameters (e.g., chlorophyll content), (2) total phenols and antioxidant activity, (3) enzyme activities (e.g., catalase), (4) plant nutrient content (macronutrients) and (5) fresh produce quantity and quality.

\section{Materials and Methods}

\subsection{Plant Material and Experimental Set Up}

The study took place at the experimental greenhouse of the Cyprus University of Technology, Limassol, Cyprus, during spring-summer of 2019. Tomato seedlings (Solanum lycopersicum cv. Brillande Grade A) were purchased from a commercial nursery. Young seedlings were transplanted in pots filled with soil (clay-loam texture, $1.41 \%$ organic matter; $24.28 \%$ total $\mathrm{CaCO}_{3} ; \mathrm{pH} 7.71$; electrical conductivity (EC) $0.68 \mathrm{mS} \mathrm{cm}^{-1}$; total nitrogen (N) $0.40 \mathrm{~g} \mathrm{~kg}^{-1}$ ).

An eco-product (EP; named as "Agriculture Green-tech E", Meydan Solution Ltd, Larnaca, Cyprus) based on rosemary (R. officinalis L. synonym of Salvia rosmarinus L.) and eucalyptus (E. globulus L.) essential oils was used. The main constituents of rosemary oil were 1,8-cineole (32.94\%), $\alpha$-pinene $(12.01 \%)$, and camphor (20.86\%) [32] and eucalyptus oil were 1,8-cineole (74.3\%) and $\alpha$-terpineol $(10.3 \%)$ [33]. This product was a mixture of these two essential oils (eucalyptus: rosemary in approximately 2:1 $v / v$ ratio) and it also contained vinegar $<5 \% w / w$ as well as emulsifier-treated water $(<80 \%)$. A commercial product (Razormin Atlantica agricola SA; Alicante, Spain) based on amino acids 
and biostimulants was used at $0.25 \% v / v$ as a positive control. Razormin contains free amino acids $7 \%$ $w / w$, iron $(\mathrm{Fe}) 0.4 \% w / w$, manganese $(\mathrm{Mn}) 0.1 \% w / w$, zinc $(\mathrm{Zn}) 0.085 \% w / w$, copper $(\mathrm{Cu}) 0.02 \% w / w$, boron (B) $0.1 \% w / w$ and molybdenum (Mo) $0.01 \% w / w$, all water soluble.

\subsection{Preliminary Test}

A preliminary experimental set up was conducted to determine the possible phytotoxicity effects of the EP on tomato plants after application via spraying. Tomato seedlings were transplanted in soil in $5 \mathrm{~L}$ pots. Seven concentrations of the EP were evaluated, from 0 to $3 \%(v / v)$ at $0.5 \%$ increments. Plants at a stage of 2-3 true leaves were transplanted and grown for 25 days, at the same environmental conditions as the main experiment (see Section 2.3 and Figure S1). Three replications were used for each concentration, resulting in a total of 21 tomato plants. Plants were monitored for phytotoxicity (marked spots) every second day for a period of 10 days. Based on the results of the preliminary experiment, the concertation of $2.0 \%(v / v)$ was selected for further evaluation, as this was the highest concentration at which no phytotoxicity effects were observed in tomato.

\subsection{Main Experiment}

A total of eighty-four young tomato seedlings were transplanted individually in 9-L pots filled with soil. The pots were placed in twin rows, with plants spaced $0.45 \mathrm{~m}$ from each other within the row, at $0.8 \mathrm{~m}$ within twin rows, and $1.2 \mathrm{~m}$ between rows. Tomato plants were trained on a string according to the single pruning scheme (the main stem grew vertically and all lateral shoots were removed) and were grown for 13 weeks.

Drip irrigation emitters ( 1 emitter/pot) were installed and irrigation occurred daily for $5 \mathrm{~min}$ at the early stage of plant development; after the 4th week, plants were watered every second day for $10 \mathrm{~min}$, or according to crop needs, using a timer. Fertigation (EC: $2.5 \mathrm{mS} \mathrm{cm}^{-1} ; 200 \mathrm{~mL} \mathrm{plant}^{-1}$ ) with commercial (i.e., 20-20-20) fertilizers was applied once, 10 days after transplanting (DAT) of seedlings in pots. Yellow sticky traps were placed to monitor insects, and pesticides were applied following common cultivation practices. In brief, 15 DAT foliar spraying for two-spotted spider mite (Tetranychus urticae) and whitefly (Bemisia tabaci) with Oberon ${ }^{\circledR}$ SC 240 (Bayer Hellas ABEE, Athens, Greece) at $0.06 \% v / v$ as well as 23 DAT foliar spraying for vegetable leaf miner (Liriomyza spp). with Tracer 48SC (Spinosad, Dow Agrosciences Export SAS, Montigny-le-Bretonneux, France) at $0.05 \% v / v$. Average day and night temperature and relative humidity during the growing period were recorded with a meteorological station and are shown in Figure S1.

Plants were assigned into one of four treatments (Supplementary material Figure S2): (i) plants sprayed with water as a control (ii) foliar spray with the Razormin commercial product (CP) at $2.5 \mathrm{~mL} \mathrm{~L}^{-1}$ every 20 days beginning on day 31 after transplanting, for a total of three applications (iii) foliar spray with the EP at $2 \%$ once (EP-1x) and (iv) foliar spray with the EP at $2 \%$ every 20 days for a total of three applications (EP-3x). Multiple foliar sprays took place every 20 days. The first spray was at the 1st fruit setting. Each treatment was replicated in three plots and each plot had seven plants in a complete randomized design (see Figure S2).

\subsection{Plant Growth and Physiological Parameters}

Plant growth-related parameters were evaluated on site. Tomato plant height, leaf number, plant fresh and dry biomass were measured on six replicates per treatment. Plant yield as the total harvested fruit for each plant (21 plant/treatment) was measured through the whole harvesting period, and yield was expressed as $\mathrm{kg}$ of fruits per plant.

Leaf tissue (four replications per treatment; each replicate consisted of a pool of 2-3 different plant tissue samples; $0.1 \mathrm{~g}$ ) was incubated in a heat bath at $65^{\circ} \mathrm{C}$ for $30 \mathrm{~min}$, in the dark, with $10 \mathrm{~mL}$ dimethyl sulfoxide (DMSO) for chlorophyll extraction. Photosynthetic pigments, i.e., chlorophyll a (Chl a), chlorophyll b (Chl b) and total chlorophyll (total $\mathrm{Chl}$ ) contents were calculated as described by Chrysargyris et al. [34]. Maximum $\mathrm{F}_{\mathrm{v}} / \mathrm{F}_{\mathrm{m}}$ photochemical quantum yields of photosystem II (PSII) were 
measured with an OptiSci OS-30p Chlorophyll Fluorometer (Opti-Sciences). Leaves were incubated in the dark for $20 \mathrm{~min}$ prior to $\mathrm{F}_{\mathrm{v}} / \mathrm{F}_{\mathrm{m}}$ measurements. Leaf stomatal conductance was measured on the 4 th-5th leaf from the top of the plant (2 measurements per leaf in each plant), by using a $\Delta \mathrm{T}$-Porometer AP4 (Delta-T Devices-Cambridge, UK) according to the manufacturer's instructions [32]. All leaves were fully mature and sun-exposed in different individual plants (4 plants/treatment).

\subsection{Total Phenols Content and Antioxidant Activity}

Total phenols content in leaves (four replications per treatment; each replicate consisted of a pool of 2-3 different plant leaf tissue samples) was determined with the Folin-Ciocalteu method at $755 \mathrm{~nm}$ according to Chondraki et al. [35], and results were expressed as equivalents of gallic acid per gram of fresh weight ( $\mu \mathrm{mol}$ of GAE $\mathrm{g}^{-1}$ fresh weight). The antioxidant capacity was measured using the ferric reducing antioxidant power (FRAP) and the 2,2-diphenyl-1-picrylhydrazyl (DPPH) methods as previously described [36]. The results for antioxidant activities were expressed as trolox equivalents (mg of trolox $\mathrm{g}^{-1}$ fresh weight).

\subsection{Hydrogen Peroxide, Lipid Peroxidation and Antioxidative Enzyme Activities}

Hydrogen peroxide $\left(\mathrm{H}_{2} \mathrm{O}_{2}\right)$ content in leaves was determined as described previously [36]. Leaf tissue (four replicates/treatment; $0.2 \mathrm{~g}$ ) was homogenized in ice-cold $0.1 \%$ trichloroacetic acid (TCA) and centrifuged at $15,000 \times g$ for $15 \mathrm{~min}$, and an aliquot of the supernatant was used for the reaction mixture. The $\mathrm{H}_{2} \mathrm{O}_{2}$ concentration was evaluated using standards prepared from dilutions of $\mathrm{H}_{2} \mathrm{O}_{2}$. The absorbance was measured at $390 \mathrm{~nm}$, and results were expressed as $\mu \mathrm{mol} \mathrm{H}_{2} \mathrm{O}_{2} \mathrm{~g}^{-1}$ fresh weight. Lipid peroxidation was assessed and measured in terms of the malondialdehyde content (MDA) [36]. Absorbance of the reaction mixture was measured at $532 \mathrm{~nm}$ and corrected at $600 \mathrm{~nm}$. The amount of MDA was determined using the extinction coefficient of $155 \mathrm{mM}^{-1} \mathrm{~cm}^{-1}$. Results were expressed as nmol of MDA ${ }^{-1}$ fresh weight.

For antioxidative enzyme activities, fresh leaf tissue (four replicates/treatment) was homogenized using an ice-cold extraction buffer containing $1 \mathrm{mM}$ ethylenediaminetetraacetic acid (EDTA), $1 \%(w / v)$ polyvinylpyrrolidone (PVPP), $1 \mathrm{mM}$ phenylmethylsulfonyl fluoride (PMSF) and $0.05 \%$ Triton X-100 in $50 \mathrm{mM}$ potassium-phosphate buffer ( $\mathrm{pH}$ 7.0). Protein content was determined using bovine serum albumin (BSA) as a standard [36]. Catalase activity (CAT) (EC 1.11.1.6), superoxide dismutase activity (SOD) (EC 1.15.1.1) and peroxidase activity (POD) (EC 1.11.1.6) were assayed following the methods described previously [36]. In brief, catalase activity was assayed in a reaction mixture $(1.5 \mathrm{~mL})$ containing $50 \mathrm{mM} \mathrm{K-phosphate} \mathrm{buffer} \mathrm{(} \mathrm{pH} 7.0), 10 \mathrm{mM} \mathrm{H}_{2} \mathrm{O}_{2}$ and plant extract. The decomposition of $\mathrm{H}_{2} \mathrm{O}_{2}$ was measured at $240 \mathrm{~nm}$. The results were expressed as CAT units $\mathrm{mg}^{-1}$ of protein $(1 \mathrm{unit}=1 \mathrm{mM}$ of $\mathrm{H}_{2} \mathrm{O}_{2}$ reduction $\left.\mathrm{min}^{-1}\right)$. SOD was assayed using a photochemical method; a reaction mixture $(1.5 \mathrm{~mL})$ containing $50 \mathrm{mM}$ K-phosphate buffer (pH 7.5), $13 \mathrm{mM}$ methionine, $75 \mu \mathrm{M}$ nitro blue tetrazolium (NBT), $0.1 \mathrm{mM}$ EDTA, $2 \mu \mathrm{M}$ riboflavin and plant extract was used. The reaction began by exposing the mixture to a light source of two 15-W fluorescent lamps for $15 \mathrm{~min}$, and terminated by placing the tubes in the dark. Absorbance was determined at $560 \mathrm{~nm}$, and activity was expressed as units $\mathrm{mg}^{-1}$ of protein. Peroxidase activity (POD) (EC 1.11.1.6) was determined following the increase in absorbance at $430 \mathrm{~nm}$. Calculations were performed using the coefficient of extinction of $2.47 \mathrm{mM} \mathrm{cm}^{-1}$. One POD unit was defined as the amount of enzyme to decompose $1 \mu \mathrm{mol}$ of $\mathrm{H}_{2} \mathrm{O}_{2}$ per minute. Results were expressed as units of peroxidase per milligram of protein.

\subsection{Plant Nutrient Content}

The nutrient content in leaves (four replications per treatment; each replicate consisted of a pool of 2-3 different plant tissue samples) was determined. Leaves were collected, dried at $65^{\circ} \mathrm{C}$ for $4 \mathrm{~d}$, weighed, and ground in a Wiley mill to pass through 40 mesh screens as described in Chrysargyris et al. [32]. Nitrogen (N) content was determined by the Kjeldahl method (BUCHI, Digest automat K-439 and Distillation Kjelflex K-360, Flawil, Switzerland) [37]. Potassium (K) and sodium (Na) 
were determined photometrically (Flame photometer, Lasany Model 1832, Lasany International, Panchkula, India), phosphorus (P) was determined spectrophotometrically (Multiskan GO, Thermo Fischer Scientific, Waltham, MA, USA), and magnesium (Mg) and calcium (Ca) by an atomic absorption spectrophotometer (PG Instruments AA500FG, Leicestershire, UK) following Chrysargyris et al. [37]. Data were expressed in $\mathrm{g} \mathrm{kg}^{-1}$ of dry weight.

\subsection{Fresh Produce Quality}

Tomatoes freshly harvested from the 2 nd truss were evaluated for their quality attributes. At least six biological replicates (pool of 2-3 fruit subsamples or sub-measurements) were used in each treatment. Number of fruits, mean fresh weight and yield were recorded.

Fruit firmness was assessed at two points on each tomato's shoulder using a texture-meter FT 011 (TR Scientific Instruments, Forli, Italy) with an 8-mm plunger. The amount of force (in Newtons; N) needed to break through a tomato's radial pericarp (i.e., surface) in eight replicates was measured at room temperature [38].

Color was measured using the Hunter Lab System and a Minolta colorimeter model CR400 (Konica Minolta, Osaka, Japan). Following the recording at 2 points of each tomato for the individual $L^{*}, a^{*}$, and $b^{*}$ parameters, chroma value (C) was calculated by the following equations $C=\left(a^{* 2}+b^{* 2}\right)^{1 / 2}$ as described previously [38].

Tomato juice was obtained from 2-3 pooled fruit for each replication (with six replicates per treatment), and total soluble solids (TSS, expressed in percentage) measured with a temperaturecompensated digital refractometer (model Atago PR-101, Atago Co. Ltd., Tokyo, Japan) at $20{ }^{\circ} \mathrm{C}$. Titratable acidity (TA) was measured via potentiometric titration (Mettler Toledo DL22, Columbus, $\mathrm{OH}$, USA) of $5 \mathrm{~mL}$ supernatant diluted to $50 \mathrm{~mL}$ with distilled water using $0.1 \mathrm{~N} \mathrm{NaOH}$ up to $\mathrm{pH}$ 8.1. Results were expressed in citric acid percentage [39]. The fruit sweetness/ripening index was calculated using TSS/TA ratio. Fruit juice $\mathrm{pH}$ and EC were also measured.

Ascorbic acid (AA) was determined by the 2,6-Dichloroindophenol titrimetric method as described previously [38]. An aliquot of $5 \mathrm{~mL}$ of pooled tomato juice was diluted with $5 \mathrm{~mL}$ of water and was titrated by the dye solution until the color changed. Data were expressed as mg of AA per gram of fresh weight.

Total phenolic content was measured on blended fruit tissue $(5 \mathrm{~g})$ extracts following repeated (4-fold) addition of $2.5 \mathrm{~mL}$ of $50 \%(v / v)$ methanol as reported previously [35]. Results were expressed as gallic acid equivalents (GAE) per gram of fresh weight.

Fresh produce marketability, aroma and appearance were recorded by using a 1-10 scale (1: not marketable quality (i.e., malformation, wounds, infection); 3: low marketable with malformation; 5: marketable with few defects i.e., small size, decolorization (medium quality); 8: marketable (good quality); 10: marketable with no defects (extra quality)) and results were expressed in percentage [38].

Additionally, symptoms of blossom end rot (BER), cracking, insect attack and russeting were recorded and results expressed in percentages.

\subsection{Statistical Methods}

Statistical analysis was performed using IBM SPSS version 22 comparing data means $( \pm$ SE) with one way-ANOVA, and Duncan's multiple range tests were calculated at $p<0.05$. Measurements were performed in four-to-six biological replications/treatment (each replication consisted of a pool of two to three individual measurements/sample).

\section{Results}

Foliar application with CP or EP affected plant growth-related attributes (Table 1). The application of an eco-product once (EP-1x) increased (by 19\%) plant height compared to the control. Tomato yield was increased with the foliar applications but differed significantly only in the case of EP-3x application compared to the control treatment. The highest plant dry weight was found in the CP application 
and significantly differed from the control and EP-3x treatment. Plant biomass, leaf and fruit number did not differ among the different foliar applications. Blossom-end-rot (BER) symptoms were absent in EP-1x-treated plants while BER levels were at $4.13 \%, 6.59 \%$ and $4.20 \%$ for the control, CP and EP-3x, respectively. Application of EP-3x was associated with a higher percentage of fruit cracking in comparison to control and CP applications. Symptoms of insect injury (average 1.22\%) and russeting (average $1.29 \%$ ) were similar to all treatments (data not presented).

Table 1. Yield and plant growth characteristics of tomato plants in relation to biostimulants foliar application.

\begin{tabular}{ccccc}
\hline Plant Growth & Control & CP & EP-1x & EP-3x \\
\hline Height $(\mathrm{m})$ & $1.47 \pm 0.03 \mathrm{~b}$ & $1.59 \pm 0.05 \mathrm{ab}$ & $1.75 \pm 0.05 \mathrm{a}$ & $1.63 \pm 0.09 \mathrm{ab}$ \\
Leaf number & $28.33 \pm 0.42 \mathrm{a}$ & $30.00 \pm 1.29 \mathrm{a}$ & $32.17 \pm 1.25 \mathrm{a}$ & $29.00 \pm 1.65 \mathrm{a}$ \\
Plant biomass $(\mathrm{g})$ & $433.90 \pm 30.39 \mathrm{a}$ & $510.75 \pm 41.27 \mathrm{a}$ & $524.48 \pm 70.38 \mathrm{a}$ & $421.33 \pm 42.99 \mathrm{a}$ \\
Plant dry weight $(\mathrm{g})$ & $83.88 \pm 3.98 \mathrm{~b}$ & $107.38 \pm 6.41 \mathrm{a}$ & $93.43 \pm 8.15 \mathrm{ab}$ & $82.93 \pm 5.86 \mathrm{~b}$ \\
Yield $\left(\right.$ kg plant $\left.^{-1}\right)$ & $0.58 \pm 0.06 \mathrm{~b}$ & $0.74 \pm 0.05 \mathrm{ab}$ & $0.71 \pm 0.06 \mathrm{ab}$ & $0.79 \pm 0.06 \mathrm{a}$ \\
Fruit number & $9.58 \pm 0.89 \mathrm{a}$ & $9.46 \pm 0.63 \mathrm{a}$ & $9.10 \pm 0.79 \mathrm{a}$ & $10.00 \pm 0.41 \mathrm{a}$ \\
Blossom end rot (BER) $(\%)$ & $4.13 \pm 2.80 \mathrm{a}$ & $6.59 \pm 2.16 \mathrm{a}$ & $0.00 \pm 0.00 \mathrm{~b}$ & $4.20 \pm 2.03 \mathrm{a}$ \\
Fruit cracking (\%) & $8.23 \pm 2.06 \mathrm{~b}$ & $7.97 \pm 2.68 \mathrm{~b}$ & $12.77 \pm 3.05 \mathrm{ab}$ & $18.43 \pm 2.688 \mathrm{a}$ \\
\hline
\end{tabular}

Control: foliar application of water; CP: commercial product; EP: eco-product; 1x: indicates application once; $3 \mathrm{x}$ : indicates three applications. Means $\pm \mathrm{SE}$ in the same row followed by different letters are significantly different according to Duncan's MRT ( $p=0.05)$.

Plants subjected to EP-1x showed higher stomatal conductance compared with the plants sprayed with water (control) (Table 2). Interestingly, EP-1x-treated plants had increased content of chlorophylls (chlorophyll a, chlorophyll b and total chlorophylls) compared to control, CP or EP-3x treatments. However, leaf chlorophyll fluorescence was similar in all treatments and averaged at 0.825 of the $\mathrm{Fv} / \mathrm{Fm}$ value.

Table 2. Leaf stomatal conductance, chlorophyll fluorescence and content of chlorophyll a, chlorophyll $\mathrm{b}$ and total chlorophylls of tomato plants in relation to biostimulants foliar application.

\begin{tabular}{ccccc}
\hline Plant Physiology & Control & CP & EP-1x & EP-3x \\
\hline Stomatal conductance $\left(\mathrm{s} \mathrm{cm}^{-1}\right)$ & $1.18 \pm 0.16 \mathrm{~b}$ & $1.56 \pm 0.13 \mathrm{ab}$ & $1.81 \pm 0.21 \mathrm{a}$ & $1.59 \pm 0.21 \mathrm{ab}$ \\
Chlorophyll fluorescence $(\mathrm{Fv} / \mathrm{Fm})$ & $0.82 \pm 0.01 \mathrm{a}$ & $0.83 \pm 0.00 \mathrm{a}$ & $0.82 \pm 0.01 \mathrm{a}$ & $0.83 \pm 0.00 \mathrm{a}$ \\
Chlorophyll a $\left(\mathrm{mg} \mathrm{g}^{-1} \mathrm{Fw}\right)$ & $0.31 \pm 0.07 \mathrm{~b}$ & $0.29 \pm 0.03 \mathrm{~b}$ & $0.65 \pm 0.06 \mathrm{a}$ & $0.25 \pm 0.03 \mathrm{~b}$ \\
Chlorophyll b $\left(\mathrm{mg} \mathrm{g}^{-1} \mathrm{Fw}\right)$ & $0.08 \pm 0.02 \mathrm{~b}$ & $0.07 \pm 0.01 \mathrm{~b}$ & $0.17 \pm 0.02 \mathrm{a}$ & $0.06 \pm 0.01 \mathrm{~b}$ \\
Total Chlorophylls $\left(\mathrm{mg} \mathrm{g}^{-1} \mathrm{Fw}\right)$ & $0.39 \pm 0.09 \mathrm{~b}$ & $0.37 \pm 0.03 \mathrm{~b}$ & $0.82 \pm 0.08 \mathrm{a}$ & $0.31 \pm 0.04 \mathrm{~b}$ \\
\hline
\end{tabular}

Control: foliar application of water; CP: commercial product; EP: eco-product; 1x: indicates application once; $3 \mathrm{x}$ : indicates three applications. Means $\pm \mathrm{SE}$ in the same row followed by different letters are significantly different according to Duncan's MRT $(p=0.05)$.

Total phenols content in tomato leaves decreased with the EP-1x application compared with the EP-3x and CP, but remained at similar levels to the control treatment (Figure 1A). Antioxidant activity, as assayed by DPPH, decreased with the EP-1x application compared to control and/or CP or EP-3x applications (Figure 1B). No differences were found in FRAP antioxidant activity among treatments (Figure 1C). 

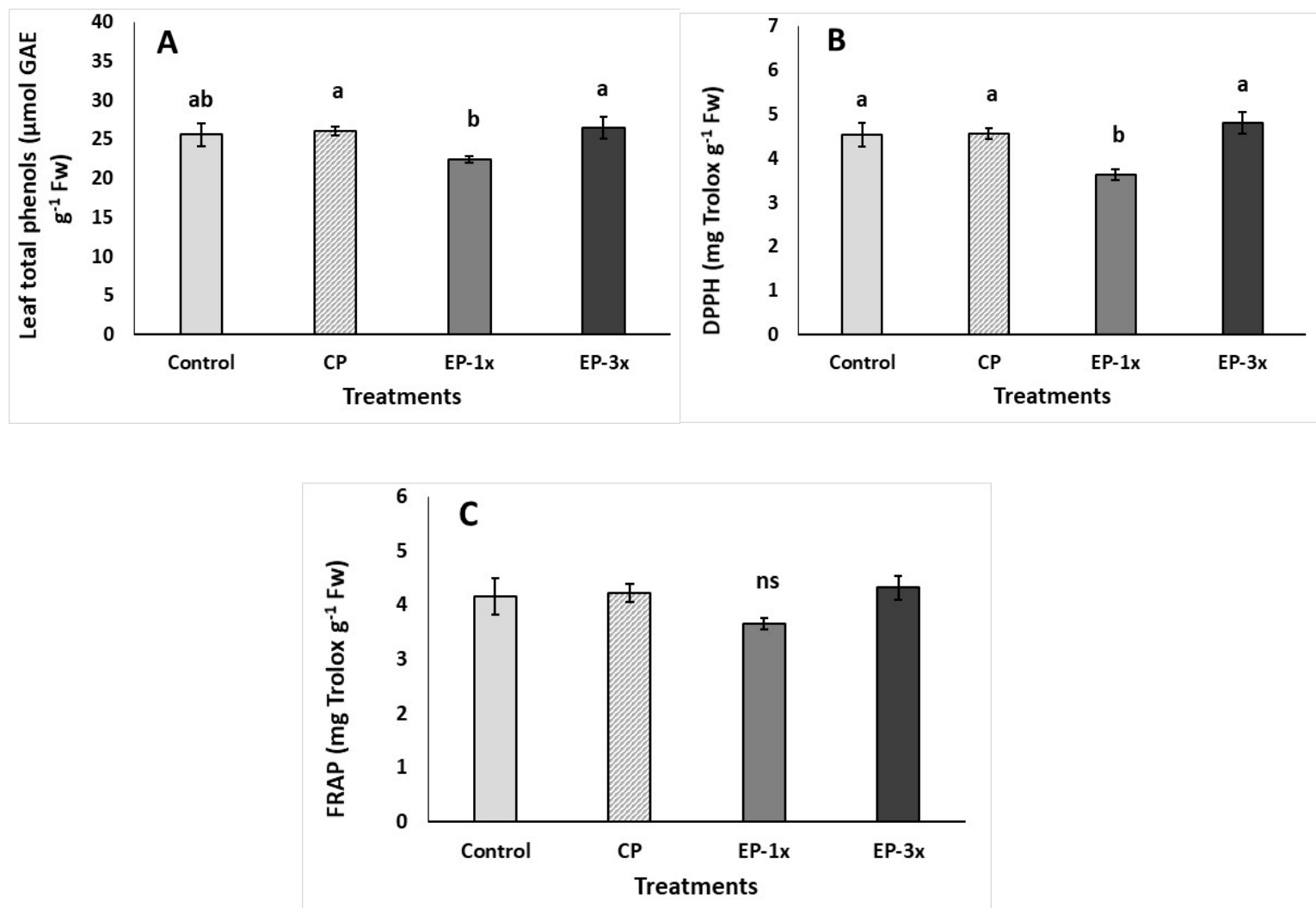

Figure 1. Total phenols content and antioxidant activity of tomato plants in relation to biostimulants foliar application (Control: foliar application of water; CP: commercial product; EP: eco-product; 1x: indicates application once; 3x: indicates three applications). (A) Total Phenols (B) DPPH and

(C) FRAP. Means \pm SE in the same row followed by different letters are significantly different according to Duncan's MRT ( $p=0.05)$; ns indicates non-significant.

Foliar application with $\mathrm{CP}$ or EP decreased (up to 27.3\%) leaf damage index indicated by the decreased lipid peroxidation (MDA) compared with the control (Figure 2A). Hydrogen peroxide production and CAT activity were similar among the treatments (Figure 2B,D). SOD activity increased with the application of EP-3x compared to the control, CP and EP-1x applications (Figure 2C). POD activity decreased with the CP and EP-1x application compared to control and EP-3x treatment (Figure 2E).
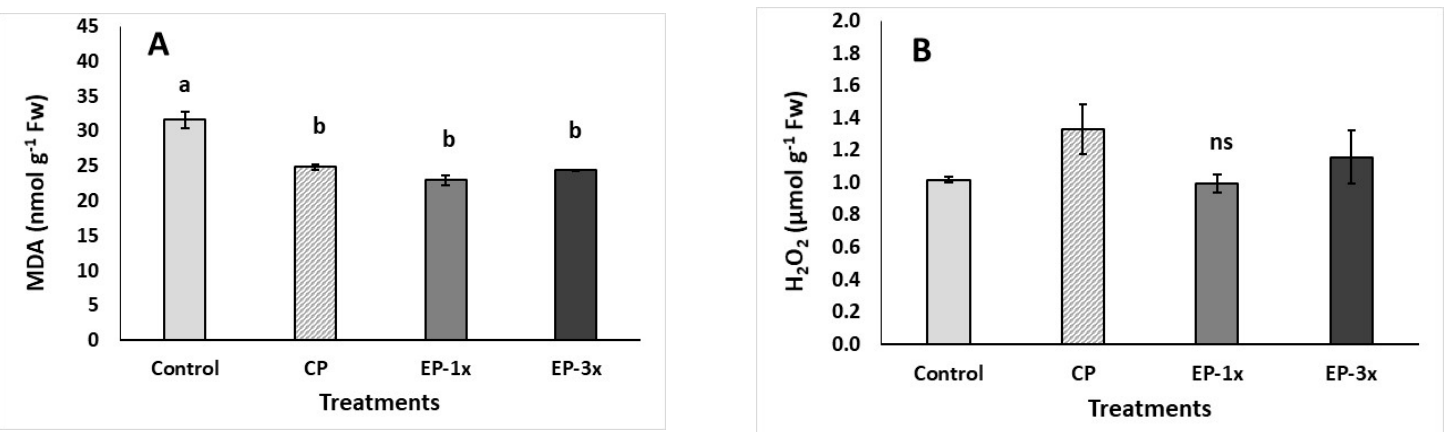

Figure 2. Cont. 

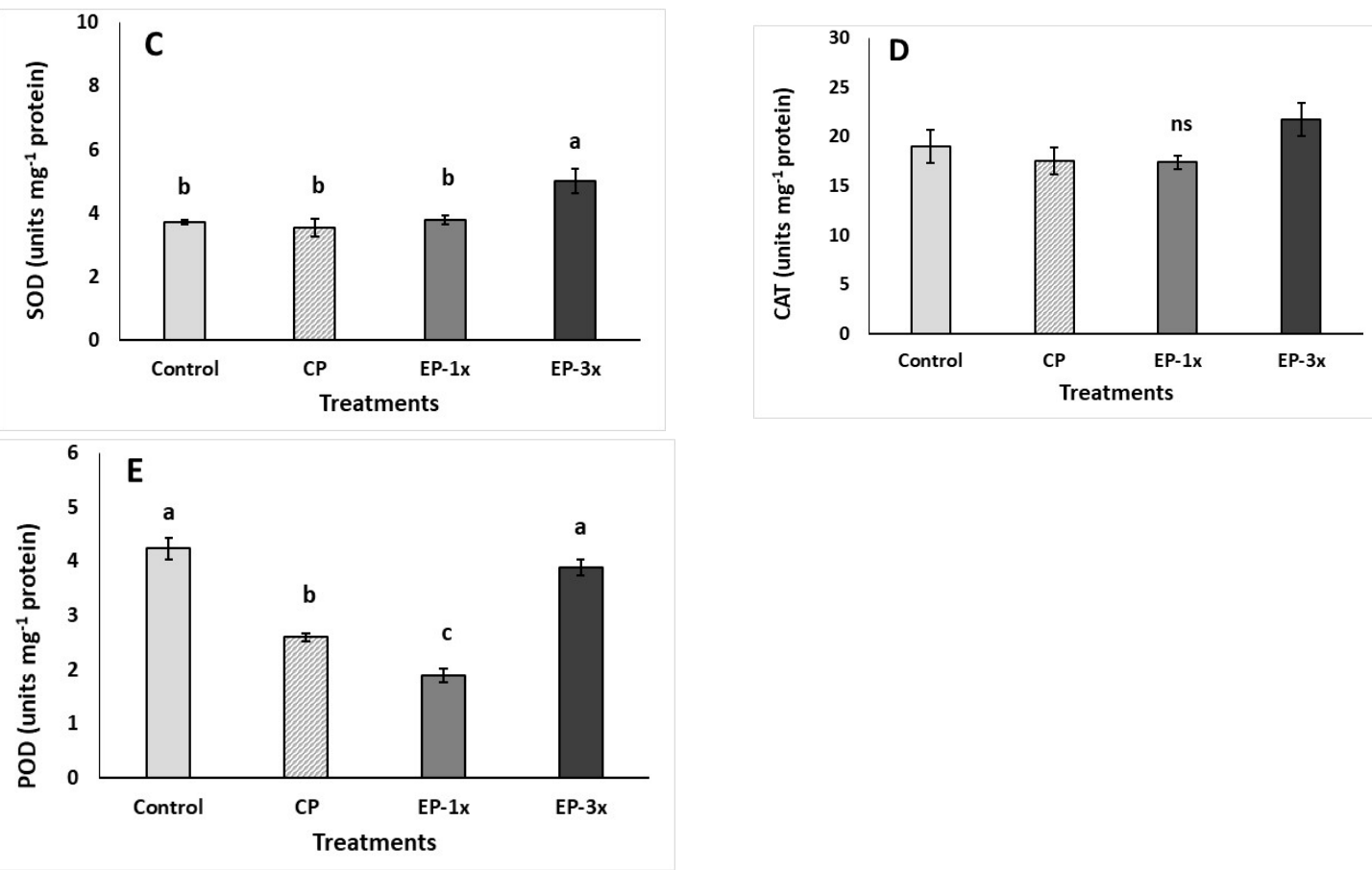

Figure 2. Damage index and antioxidant enzymes activities in tomato plants in relation to biostimulants foliar application (Control: foliar application of water; $\mathrm{CP}$ : commercial product; EP: eco-product; 1x: indicates application once; 3x: indicates three applications). (A) lipid peroxidation (malondialdehyde)-MDA, (B) hydrogen peroxide $-\mathrm{H}_{2} \mathrm{O}_{2}$, (C) superoxide dismutase- $\mathrm{SOD}$, (D) catalaseCAT, and (E) peroxidase-POD. Means \pm SE in the same row followed by different letters are significantly different according to Duncan's MRT ( $p=0.05)$; ns indicates non-significant.

Foliar applications affected the tomato leaf nutrient content as presented in Figure 3. The application of EP-3x decreased N content in leaves compared to the control (Figure 3A). $\mathrm{CP}$ application decreased but EP-3x increased $\mathrm{K}$ content in leaves compared to the control treatment (Figure 3B). Phosphorus content was decreased with the application of CP and EP-1x but was increased with the EP-3x compared to the control (Figure 3C). Application of CP or EP increased Na but decreased $\mathrm{Mg}$ content in leaves (Figure 3D,F). Calcium content was decreased in CP and EP-1x treatment compared to the control treatment (Figure 3E).
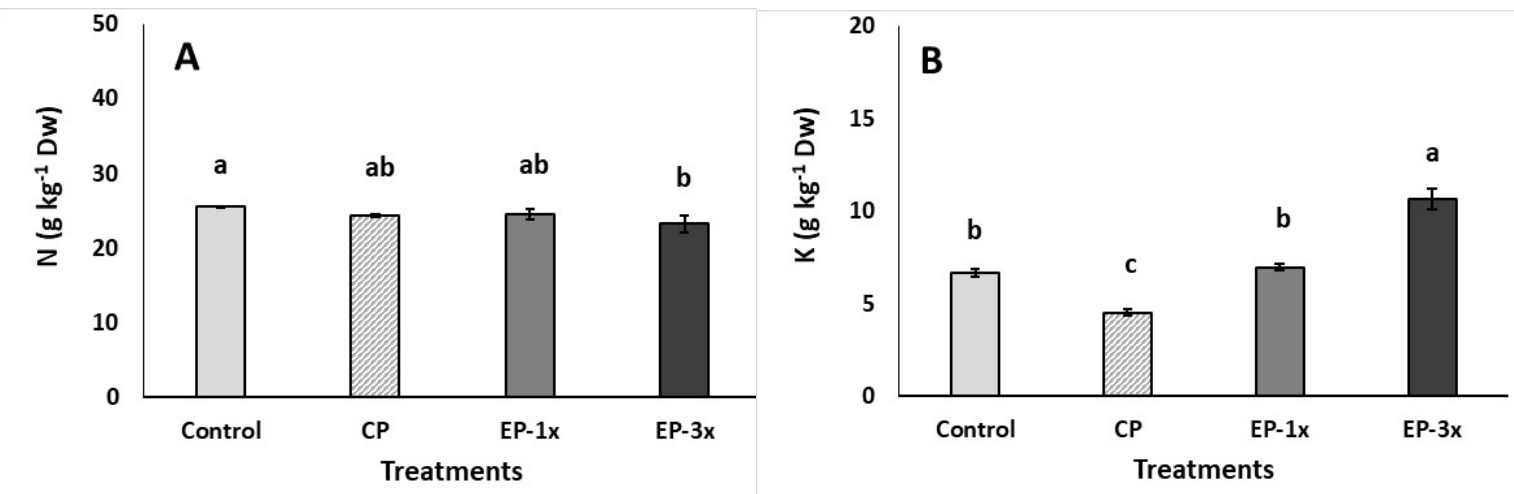

Figure 3. Cont. 


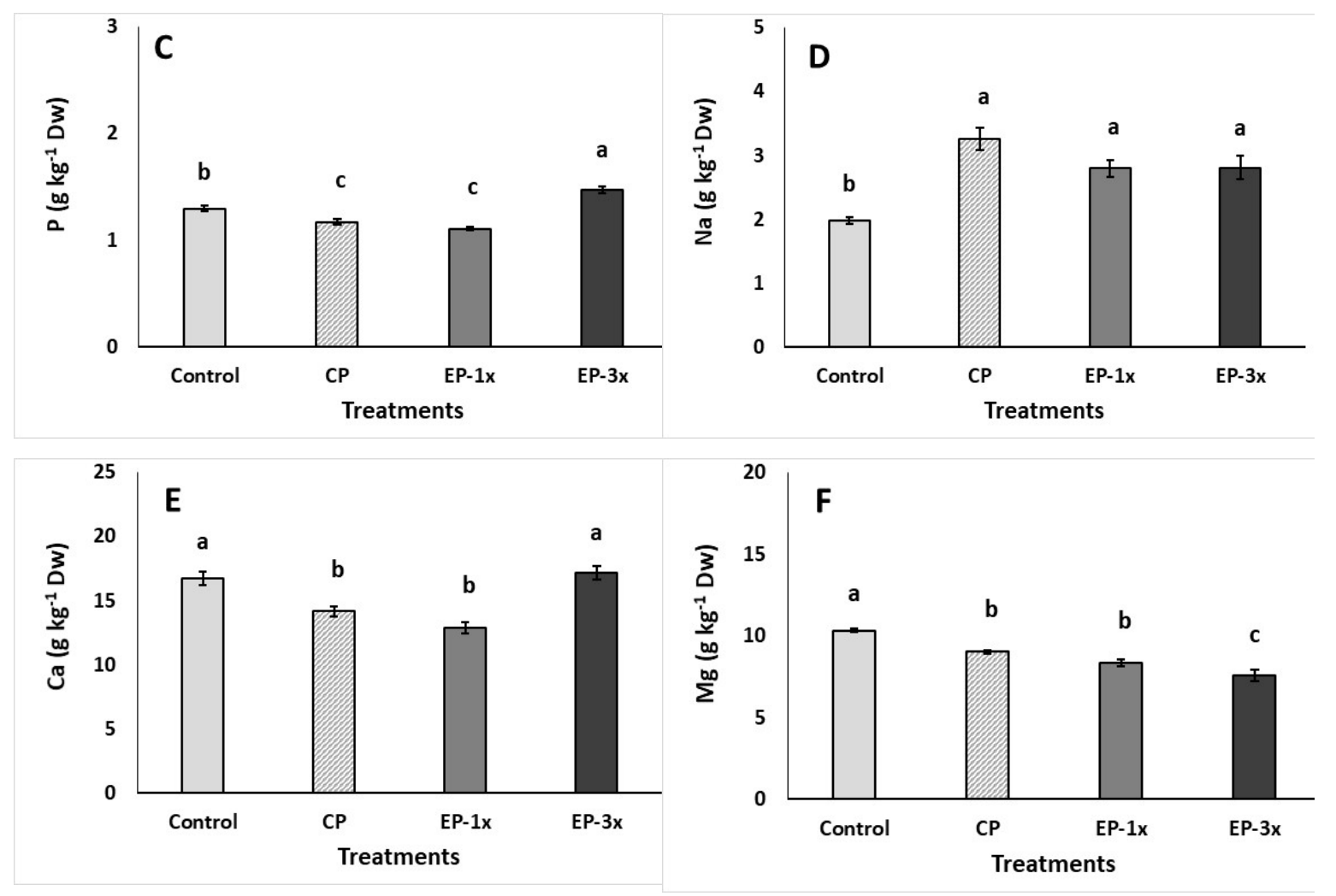

Figure 3. Nutrient content of tomato leaves in relation to biostimulants foliar application (Control: foliar application of water; CP: commercial product; EP: eco-product; 1x: indicates application once; 3x: indicates three applications). (A) nitrogen-N, (B) potassium-K, (C) phosphorus-P, (D) sodium-Na, (E) calcium-Ca, and (F) magnesium-Mg. Means \pm SE in the same row followed by different letters are significantly different according to Duncan's MRT $(p=0.05)$.

Fruit quality-related attributes by the plants subjected to different foliar applications were presented in Table 3. Fruit firmness decreased by $19.5 \%$ and $19.9 \%$ in CP and EP-1x treated plants, respectively, compared to the plants sprayed with water (control). Total phenolics and titratable acidity decreased with the application of CP or EP compared to the control. Foliar applications of CP and EP affected fruit sweetness as indicated by ripening index of TSS/TA ratio, and revealed the highest values with the EP-1x treatment. The higher ascorbic acid content was observed in tomatoes harvested by plants subjected to the EP-1x treatment, as AA was almost doubled in EP-1x compared to control. Fruit marketability and tomato-like aroma did not differ among the treatments; however, tomato appearance had the highest score in EP-1x compared to control and CP applications. Fruit fresh weight (averaged in $88.01 \mathrm{~g}$ ) and total soluble solids (averaged in $5.14^{\circ}$ Brix) were similar among the treatments. 
Table 3. Fruit quality related attributes harvested from tomato plants in relation to biostimulants foliar application.

\begin{tabular}{ccccc}
\hline Quality Attributes & Control & CP & EP-1x & EP-3x \\
\hline Fruit fresh weight-Fw $(\mathrm{g})$ & $80.93 \pm 3.4 \mathrm{a}$ & $94.4 \pm 5.36 \mathrm{a}$ & $95.22 \pm 6.65 \mathrm{a}$ & $81.49 \pm 4.69 \mathrm{a}$ \\
Firmness (Newton) & $12.75 \pm 0.97 \mathrm{a}$ & $10.27 \pm 0.32 \mathrm{~b}$ & $10.21 \pm 0.54 \mathrm{~b}$ & $10.74 \pm 0.75 \mathrm{ab}$ \\
Total soluble solids-TSS ( $\left.{ }^{\circ} \mathrm{Brix}\right)$ & $5.30 \pm 0.26 \mathrm{a}$ & $5.10 \pm 0.18 \mathrm{a}$ & $5.08 \pm 0.14 \mathrm{a}$ & $5.08 \pm 0.22 \mathrm{a}$ \\
Titratable acidity-TA (citric acid g L ${ }^{-1}$ ) & $5.26 \pm 0.24 \mathrm{a}$ & $4.14 \pm 0.11 \mathrm{~b}$ & $3.58 \pm 0.12 \mathrm{c}$ & $3.95 \pm 0.16 \mathrm{bc}$ \\
TSS/TA & $1.01 \pm 0.04 \mathrm{c}$ & $1.23 \pm 0.02 \mathrm{~b}$ & $1.42 \pm 0.03 \mathrm{a}$ & $1.28 \pm 0.03 \mathrm{~b}$ \\
Ascorbic acid-AA (mg 100 g $\left.{ }^{-1} \mathrm{Fw}\right)$ & $73.80 \pm 3.71 \mathrm{~b}$ & $79.87 \pm 8.11 \mathrm{~b}$ & $147.02 \pm 4.66 \mathrm{a}$ & $85.21 \pm 3.15 \mathrm{~b}$ \\
Phenols ( $\mu$ mol GAE g-1 Fw) & $3.10 \pm 0.20 \mathrm{a}$ & $2.59 \pm 0.20 \mathrm{~b}$ & $2.51 \pm 0.04 \mathrm{~b}$ & $2.51 \pm 0.11 \mathrm{~b}$ \\
Marketability $(1-10)$ & $7.83 \pm 0.49 \mathrm{a}$ & $8.58 \pm 0.40 \mathrm{a}$ & $8.67 \pm 0.17 \mathrm{a}$ & $7.75 \pm 0.31 \mathrm{a}$ \\
Aroma (1-10) & $5.50 \pm 0.53 \mathrm{a}$ & $7.00 \pm 0.41 \mathrm{a}$ & $6.75 \pm 0.28 \mathrm{a}$ & $6.33 \pm 0.69 \mathrm{a}$ \\
Appearance $(1-10)$ & $7.25 \pm 0.54 \mathrm{bc}$ & $8.25 \pm 0.40 \mathrm{ab}$ & $8.50 \pm 0.26 \mathrm{a}$ & $7.00 \pm 0.26 \mathrm{c}$ \\
\hline
\end{tabular}

Control: foliar application of water; CP: commercial product; EP: eco-product; 1x: indicates application once; $3 \mathrm{x}$ : indicates three applications. Means $\pm \mathrm{SE}$ in the same row followed by different letters are significantly different according to Duncan's MRT ( $p=0.05)$.

\section{Discussion}

The application of biostimulants affects plant metabolism and quality of end-products [40]. Przygocka-Cyna and Grzebisz [41] associated the use of biostimulants with an improvement in plant nutrient uptake and therefore with better nutritional value of the end products. In the present study, plant growth was affected by the application of the EP as well as the CP. The EP increased the height and the yield of tomato plants. However, in previous studies, high rosemary essential oil application on tomato seedlings decreased plant height and that could be related to stress signaling molecules (i.e., ethylene) [24]. The applied EP, based on an essential oils mixture, seems to have affected plant growth characteristics by acting as a biostimulant, similar to what has been shown for other organic compounds such as humic acids, amino acids, salicylic acid and vitamins [42-44]. Similar observations to our results were found after the use of products based on the marine alga Ascophyllum nodosum and foliar fertilizers with many micronutrients (Megagreen) which enhanced plant growth and production in lettuce [14]. In another study, under salinity conditions, the use of plant-derived protein hydrolysates increased fresh yield, dry biomass and root dry weight of lettuce [1]. For tomato, biostimulant treatments (tropical plant extract (PE); legume-derived protein hydrolysate (PH)) resulted in higher plant biomass, even in higher leaf area index (PH), compared to non-treated control [20]. In addition, foliar applications of protein hydrolysate, plant and seaweed extracts increased yield in tomato [21]. However, our study showed that fruit cracking, a non-desirable phenomenon for tomato fruits mainly related to differences in temperature around the fruit, irrigation water availability and water content in the plant/fruit tissue, was increased in the case of EP application. An optimized irrigation schedule could possibly prevent fruit cracking when EP is sprayed, but this needs to be further researched. Despite the fact that our study showed fruit cracking in tomato, biostimulants can be considered as a useful mean to alleviate the severe effects of water stress and enhance quality of bean (Phaseolus vulgaris L.) pods and seeds [45].

In addition, the application of EP increased stomatal conductance and it also demonstrated an effect on chlorophyll content (at EP-1x). This was in agreement with findings from a study on rosemary oil foliar application on tomato young seedlings, as chlorophyll levels (assayed by leaf SPAD) were increased at $0.1 \%$ oil foliar treatment compared to the control (water) or $0.05 \%$ soil application [24]. Stomatal conductance was related to plant water relations and photosynthesis [46]. In this case, EP application might increase water uptake in tomato plants. However, as mentioned previously, irrigation schedule (water was applied at the same time intervals) probably determined the water uptake in plants and fruit quality (i.e., cracking). It should be noted that the application of $\mathrm{CP}$ also increased stomatal conductance. Chlorophyll content (as well as carotenoids) was also increased in lettuce in another study, after the use of a foliar fertilizer containing macronutrients [14] as well as after the use of fish-derived protein hydrolysates [47]. Other products, such as chitosan (deacetylated 
form of chitin) enhanced lettuce photosynthetic activity, posing biostimulant effects on the examined crop [48].

On the other hand, in the case that the EP was applied only once, it decreased total phenols content in tomato leaves compared to CP and EP-3x treatment, but not compared to the control. Antioxidant activity (assayed with the DPPH method) decreased with the EP-1x application while no differences were found for FRAP antioxidant activity among the treatments. The above decreases might be related to the lesser stress conditions, as MDA remained at low levels and/or due to the possible biostimulant role that the EP could have on the plants. In contrast to our results, the application of amino acid-based biostimulants and amino acids in combination with $A$. nodosum filtrate significantly increased total phenols content in broccoli [8]. Additionally, the use of brown seaweed (A. nodosum) enhanced phenolic content in spinach [17].

Foliar application of $\mathrm{CP}$ and EP resulted in decreased damage to tomato leaves (Figure 2). Enzymatic activity was also affected, as determined by SOD and POD. The decreased MDA was possibly related to the primary activation of antioxidant enzymes metabolism (initial increase in SOD and then POD, causing detoxification of reactive oxygen species (ROS) and therefore enzymes activities were decreased), or other non-enzymatic processes may be involved. Wozniak et al. [49] reviewed that with over 50 biostimulants (from seaweed extracts, humic compounds, hydrolyzed proteins, live microbial inoculums to synthetic compounds) when evaluated on over 30 agronomic and horticultural crops, one of the main impacts of biostimulants was related to the control of ROS overproduction and cell membranes protection. The protective mechanisms were reflected in the increased antioxidant enzymatic activity and secondary metabolites of the plants. Nevertheless, further studies are necessary to address this concern in more detail.

The application of EP affected the nutrient content in tomato leaves. Therefore, $\mathrm{N}$ leaf content decreased when EP was applied three times (EP-3x) while $\mathrm{K}$ as well as $\mathrm{P}$ content increased. Fanasca et al. [50] reported the positive effect of $\mathrm{K}$ in fruits on lycopene content, as $\mathrm{K}$ can be involved by its action on carbohydrate metabolism, and therefore involved in the carotenoid biosynthesis process [51]. For P, EP-1x treatment decreased the nutrient content in tomato leaves. Moreover, $\mathrm{Na}$ content increased and $\mathrm{Mg}$ decreased in leaves in the case of EP and CP application, indicating antagonistic effects among cations that could possibly reach deficient levels for key macronutrients on plant physiology processes (i.e., $\mathrm{Mg}$ deficiency is affecting the plant photosynthetic rates). Similar results were presented after the application of plant and seaweed extracts in tomato plants for the nutrient content of tomato fruit [21]. Additionally, the application of salicylic acid or Moringa oleifera leaf extract improved nutrients content in bean plants [18]. Souri and Bakhtiarizade [24] reported the increased $\mathrm{N}, \mathrm{K}, \mathrm{Mg}, \mathrm{Fe}$ and $\mathrm{Zn}$ leaf content in tomato seedlings when plants were sprayed with $0.1 \%$ rosemary essential oil compared to the control and/or lower oil concentrations, indicating the beneficial effects of the essential oils to be depended on the selected rosemary oil levels. It is important to point here that biostimulants cannot be defined as fertilizers, since they do not provide nutrients directly to the plants, but indirectly could facilitate the acquisition of nutrients by supporting metabolic processes in plants and soil [4].

Fruit quality attributes are essential for the commercial success of vegetables and fruits. This study showed that fruit firmness was decreased in the case of EP or CP application, as a consequence, fruit were more subjected to the ripening process and senescence with decreased storage life [52]. Additionally, the application of CP and EP decreased total phenolics (antioxidants) and titratable acidity in tomato juice, reflecting increased ripening metabolism and fruit senescence, as was also indicated with higher TSS/TA values. Consequently, tomatoes produced under EP applications might have a shorter shelf life and additional postharvest handling might be required (i.e., ozone, 1-MCP) [52,53]. On the other hand, ascorbic acid was doubled in the case of EP-1x in comparison to the control, providing increased antioxidant status and better quality, characteristics that are well appreciated by consumers. In contrast, when tomato plants were subjected to foliar applications of protein hydrolysate, plant and seaweed extracts, the content of fruit total phenols and ascorbic acid did not differ compared 
to the control treatment [21]. Quality attributes such as fruit marketability and aroma were not affected by the application of EP. The same was observed for fruit fresh weight and total soluble solids. However, EP-1x led to the highest scores related to fruit appearance. These parameters are important for assessing fruit ripening as well as the post-harvest treatment (e.g., handling and transportation) of tomato. In another study, where plant extracts and protein hydrolysates were applied in tomato, fruit brightness and redness as well as the target organic acids malate, oxalate, citrate and isocitrate were significantly higher in treated relative to untreated plants [20].

\section{Conclusions}

In this work, the potential use of an EP containing eucalyptus and rosemary essential oils as a biostimulant was tested in tomato plants. Plant yield, quality, nutritional, physiological and enzyme activity parameters were evaluated after its use. Plant growth was affected as EP increased height and yield in tomato. The EP affected stomatal conductance as well as chlorophyll content and it decreased phenolic content in leaves. Enzymatic activity was also affected as well as nutrient content in plant leaves. In tomato juice, total phenolics and titratable acidity were decreased while ascorbic acid was increased. Fruit marketability and aroma were not affected by the EP application. This research showed that essential oils could have potential application as biostimulants, as EP-1x application revealed superior fruit quality attributes compared to EP-3x and CP, considering the cost of the farmer for triple applications compared to once. The experiment is suggested to do $5 \mathrm{x}$-EP to see weather show the similar patterns as shown in $3 \mathrm{x}-\mathrm{EP}$, and this is possible applicable in longer tomato crop cycle. Further research is required to test them in other crops as well as to identify the ingredients that are responsible for the biostimulant properties of essential oils. Considering the well-known role of 1,8-cineole, with a considerable content in rosemary and eucalyptus oils, other plant species with relevant considerable 1,8-cineole content could be tested for biostimulation, such as laurel, artemisia, lavender, to name a few.

Supplementary Materials: The following are available online at http://www.mdpi.com/2071-1050/12/20/8432/s1, Figure S1. Average day and night temperature and relative humidity during growing period, Figure S2. Experimental design for the tomato greenhouse study.

Author Contributions: Conceptualization, A.C., V.L., N.T. and M.S.; methodology, A.C., S.C., P.X. and N.T.; data curation, A.C. and N.T.; Investigation, A.C., S.C., P.X., V.L. and N.T.; writing - original draft preparation, A.C., V.L., P.X. and N.T.; writing - review and editing, A.C., V.L., N.T. and M.S.; supervision, N.T.; project administration, M.S. and N.T.; funding acquisition, M.S. All authors have read and agreed to the published version of the manuscript.

Funding: This research was funded by Cyprus Research and Innovation Foundation programmes for research, technological development and innovation "RESTART 2016-2020", grant number ENTERPRISES/0916/0025; project PlantSafe. The project is co-funded by the European Regional Development Fund and the Republic of Cyprus.

Conflicts of Interest: The authors declare no conflict of interest.

\section{References}

1. Lucini, L.; Colla, G.; Miras-Moreno, B.; Bernardo, L.; Cardarelli, M.; Terzi, V.; Bonini, P.; Rouphael, Y. Inoculation of Rhizoglomus irregulare or Trichoderma atroviride differentially modulates metabolite profiling of wheat root exudates. Phytochemistry 2019, 157, 158-167. [CrossRef] [PubMed]

2. Bulgari, R.; Cocetta, G.; Trivellini, A.; Vernieri, P.; Ferrante, A. Biostimulants and crop responses: A review. Biol. Agric. Hortic. 2014, 31, 1-17. [CrossRef]

3. Rouphael, Y.; Colla, G. Editorial: Biostimulants in Agriculture. Front. Plant Sci. 2020, 11, 40. [CrossRef] [PubMed]

4. Drobek, M.; Frą, M.; Cybulska, J. Plant Biostimulants: Importance of the Quality and Yield of Horticultural Crops and the Improvement of Plant Tolerance to Abiotic Stress-A Review. Agronmy 2019, 9, 335. [CrossRef]

5. Brown, P.H.; Saa, S. Biostimulants in agriculture. Front. Plant Sci. 2015, 6, 6. [CrossRef] 
6. Rouphael, Y.; Cardarelli, M.; Bonini, P.; Colla, G. Synergistic Action of a Microbial-based Biostimulant and a Plant Derived-Protein Hydrolysate Enhances Lettuce Tolerance to Alkalinity and Salinity. Front. Plant Sci. 2017, 8, 131. [CrossRef]

7. Van Oosten, M.J.; Pepe, O.; De Pascale, S.; Silletti, S.; Maggio, A. The role of biostimulants and bioeffectors as alleviators of abiotic stress in crop plants. Chem. Biol. Technol. Agric. 2017, 4, 5. [CrossRef]

8. Kałużewicz, A.; Gąsecka, M.; Spiżewski, T. Influence of biostimulants on phenolic content in broccoli heads directly after harvest and after storage. Folia Hortic. 2017, 29, 221-230. [CrossRef]

9. Elansary, H.O.; Mahmoud, E.A.; El-Ansary, D.O.; Mattar, M.A. Effects of Water Stress and Modern Biostimulants on Growth and Quality Characteristics of Mint. Agronmy 2019, 10, 6. [CrossRef]

10. Canellas, L.P.; Olivares, F.L.; Aguiar, N.O.; Jones, D.L.; Nebbioso, A.; Mazzei, P.; Piccolo, A. Humic and fulvic acids as biostimulants in horticulture. Sci. Hortic. 2015, 196, 15-27. [CrossRef]

11. Colla, G.; Rouphael, Y.; Di Mattia, E.; El-Nakhel, C.; Cardarelli, M. Co-inoculation of Glomus intraradices and Trichoderma atroviride acts as a biostimulant to promote growth, yield and nutrient uptake of vegetable crops. J. Sci. Food Agric. 2015, 95, 1706-1715. [CrossRef] [PubMed]

12. Litskas, V.; Chrysargyris, A.; Stavrinides, M.C.; Tzortzakis, N. Water-energy-food nexus: A case study on medicinal and aromatic plants. J. Clean. Prod. 2019, 233, 1334-1343. [CrossRef]

13. Hamedani, S.R.; Rouphael, Y.; Colla, G.; Colantoni, A.; Cardarelli, M. Biostimulants as a Tool for Improving Environmental Sustainability of Greenhouse Vegetable Crops. Sustainability 2020, 12, 5101. [CrossRef]

14. Dudaš, S.; Šola, I.; Sladonja, B.; Erhatić, R.; Ban, D.; Poljuha, D. The Effect of Biostimulant and Fertilizer on "Low Input" Lettuce Production. Acta Bot. Croat. 2016, 75, 253-259. [CrossRef]

15. Chrysargyris, A.; Xylia, P.; Anastasiou, M.; Pantelides, I.S.; Tzortzakis, N. Effects of Ascophyllum nodosum seaweed extracts on lettuce growth, physiology and fresh-cut salad storage under potassium deficiency. J. Sci. Food Agric. 2018, 98, 5861-5872. [CrossRef]

16. Pereira, C.; Dias, M.I.; Petropoulos, S.A.; Plexida, S.; Chrysargyris, A.; Tzortzakis, N.; Calhelha, R.C.; Soković, M.; Stojković, D.; Barros, L.; et al. The Effects of Biostimulants, Biofertilizers and Water-Stress on Nutritional Value and Chemical Composition of Two Spinach Genotypes (Spinacia oleracea L.). Molecules 2019, 24, 4494. [CrossRef]

17. Fan, D.; Hodges, D.M.; Zhang, J.; Kirby, C.W.; Ji, X.; Locke, S.J.; Critchley, A.T.; Prithiviraj, B. Commercial extract of the brown seaweed Ascophyllum nodosum enhances phenolic antioxidant content of spinach (Spinacia oleracea L.) which protects Caenorhabditis elegans against oxidative and thermal stress. Food Chem. 2011, 124, 195-202. [CrossRef]

18. Rady, M.M.; Mohamed, G.F. Modulation of salt stress effects on the growth, physio-chemical attributes and yields of Phaseolus vulgaris L. plants by the combined application of salicylic acid and Moringa oleifera leaf extract. Sci. Hortic. 2015, 193, 105-113. [CrossRef]

19. Goñi, O.; Quille, P.; O'Connell, S. Ascophyllum nodosum extract biostimulants and their role in enhancing tolerance to drought stress in tomato plants. Plant Physiol. Biochem. 2018, 126, 63-73. [CrossRef]

20. Caruso, G.; De Pascale, S.; Cozzolino, E.; Cuciniello, A.; Cenvinzo, V.; Bonini, P.; Colla, G.; Rouphael, Y. Yield and Nutritional Quality of Vesuvian Piennolo Tomato PDO as Affected by Farming System and Biostimulant Application. Agronmy 2019, 9, 505. [CrossRef]

21. Colla, G.; Cardarelli, M.; Bonini, P.; Rouphael, Y. Foliar Applications of Protein Hydrolysate, Plant and Seaweed Extracts Increase Yield but Differentially Modulate Fruit Quality of Greenhouse Tomato. HortScience 2017, 52, 1214-1220. [CrossRef]

22. Koleška, I.; Hasanagić, D.; Todorović, V.; Murtić, S.; Klokić, I.; Parađiković, N.; Kukavica, B. Biostimulant prevents yield loss and reduces oxidative damage in tomato plants grown on reduced NPK nutrition. J. Plant Interact. 2017, 12, 209-218. [CrossRef]

23. González-González, M.F.; Ocampo-Alvarez, H.; Santacruz-Ruvalcaba, F.; Sánchez-Hernández, C.V.; Casarrubias-Castillo, K.; Becerril-Espinosa, A.; Castañeda-Nava, J.J.; Hernández-Herrera, R.M. Physiological, Ecological, and Biochemical Implications in Tomato Plants of Two Plant Biostimulants: Arbuscular Mycorrhizal Fungi and Seaweed Extract. Front. Plant Sci. 2020, 11, 999. [CrossRef] [PubMed]

24. Souri, M.K.; Bakhtiarizade, M. Biostimulation effects of rosemary essential oil on growth and nutrient uptake of tomato seedlings. Sci. Hortic. 2019, 243, 472-476. [CrossRef]

25. Zanin, L.; Tomasi, N.; Cesco, S.; Varanini, Z.; Pinton, R. Humic Substances Contribute to Plant Iron Nutrition Acting as Chelators and Biostimulants. Front. Plant Sci. 2019, 10, 675. [CrossRef] 
26. Sfara, V.; Zerba, E.N.; Alzogaray, R.A. Fumigant insecticidal activity and repellent effect of five essential oils and seven monoterpenes on first-instar nymphs of Rhodnius prolixus. J. Med Entomol. 2009, 46, 511-515. [CrossRef]

27. Sun, Y.; Cai, X.; Cao, J.; Wu, Z.; Pan, D. Effects of 1,8-cineole on Carbohydrate Metabolism Related Cell Structure Changes of Salmonella. Front. Microbiol. 2018, 9, 1078. [CrossRef]

28. Petrović, J.; Glamočlija, J.; Marin, P.D.; Brkić, D.; Van Griensven, L.J. Antibacterial Effects of the Essential Oils of Commonly Consumed Medicinal Herbs Using an In Vitro Model. Molecules 2010, 15, 7532-7546. [CrossRef]

29. Bedoya-Pérez, M.A.; Isler, I.; Banks, P.B.; McArthur, C. Roles of the volatile terpene, 1,8-cineole, in plant-herbivore interactions: A foraging odor cue as well as a toxin? Oecologia 2013, 174, 827-837. [CrossRef]

30. Tzortzakis, N. Maintaining postharvest quality of fresh produce with volatile compounds. Innov. Food Sci. Emerg. Technol. 2007, 8, 111-116. [CrossRef]

31. Caldas, G.F.R.; Oliveira, A.R.D.S.; Araújo, A.V.; Lafayette, S.S.L.; Albuquerque, G.; Silva-Neto, J.D.C.; Costa-Silva, J.H.; Ferreira, F.; Da Costa, J.G.M.; Wanderley, A.G. Gastroprotective Mechanisms of the Monoterpene 1,8-Cineole (Eucalyptol). PLOS ONE 2015, 10, e0134558. [CrossRef]

32. Chrysargyris, A.; Xylia, P.; Akinci, G.; Moustakas, K.; Tzortzakis, N. Printed Paper Waste as an Alternative Growing Medium Component to Produce Brassica Seedlings under Nursery Conditions. Sustainability 2020, 12, 5992. [CrossRef]

33. Inouye, S.; Takizawa, T.; Yamaguchi, H. Antibacterial activity of essential oils and their major constituents against respiratory tract pathogens by gaseous contact. J. Antimicrob. Chemother. 2001, 47, 565-573. [CrossRef] [PubMed]

34. Chrysargyris, A.; Nikolaidou, E.; Stamatakis, A.; Tzortzakis, N. Vegetative, physiological, nutritional and antioxidant behavior of spearmint (Mentha spicata L.) in response to different nitrogen supply in hydroponics. J. Appl. Res. Med. Aromat. Plants 2017, 6, 52-61. [CrossRef]

35. Chondraki, S.; Tzerakis, C.; Tzortzakis, N. Influence of sodium chloride and calcium foliar spray on hydroponically grown parsley in nutrient film technique system. J. Plant Nutr. 2012, 35, 1457-1467. [CrossRef]

36. Chrysargyris, A.; Papakyriakou, E.; Petropoulos, S.A.; Tzortzakis, N. The combined and single effect of salinity and copper stress on growth and quality of Mentha spicata plants. J. Hazard. Mater. 2019, 368, 584-593. [CrossRef] [PubMed]

37. Chrysargyris, A.; Antoniou, O.; Tzionis, A.; Prasad, M.; Tzortzakis, N. Alternative soilless media using olive-mill and paper waste for growing ornamental plants. Environ. Sci. Pollut. Res. 2018, 25, 35915-35927. [CrossRef]

38. Xylia, P.; Clark, A.; Chrysargyris, A.; Romanazzi, G.; Tzortzakis, N. Quality and safety attributes on shredded carrots by using Origanum majorana and ascorbic acid. Postharvest Biol. Technol. 2019, 155, 120-129. [CrossRef]

39. Tzortzakis, N.; Saridakis, C.; Chrysargyris, A. Treated Wastewater and Fertigation Applied for Greenhouse Tomato Cultivation Grown in Municipal Solid Waste Compost and Soil Mixtures. Sustainability 2020, 12, 4287. [CrossRef]

40. Colla, G.; Nardi, S.; Cardarelli, M.; Ertani, A.; Lucini, L.; Canaguier, R.; Rouphael, Y. Protein hydrolysates as biostimulants in horticulture. Sci. Hortic. 2015, 196, 28-38. [CrossRef]

41. Przygocka-Cyna, K.; Grzebisz, W. Effect of biofertilizers on nutrient uptake by vegetables grown in a short cropping sequence. J. Elem. 2018, 23, 807-823. [CrossRef]

42. Souri, M.K.; Roemheld, V. Split daily application of ammonium cannot ameliorate ammonium toxicity in tomato plants. Hortic. Environ. Biotechnol. 2009, 50, 384-391.

43. Rose, M.T.; Patti, A.F.; Little, K.R.; Brown, A.L.; Jackson, W.R.; Cavagnaro, T.R. A meta-analysis and review of plant-growth response to humic substances: Practical implications for agriculture. Adv. Agron. 2014, 124, 37-89.

44. Denre, M.; Ghanti, S.; Sarkar, K. Effect of humic acid application on accumulation of mineral nutrition and pungency in garlic (Allium satioum L.). Int. J. Biotechnol. Mol. Biol. Res. 2014, 5, 7-12.

45. Petropoulos, S.A.; Fernandes, Â.; Plexida, S.; Chrysargyris, A.; Tzortzakis, N.; Barreira, J.C.M.; Barros, L.; Ferreira, I.C. Biostimulants Application Alleviates Water Stress Effects on Yield and Chemical Composition of Greenhouse Green Bean (Phaseolus vulgaris L.). Agronomy 2020, 10, 181. [CrossRef] 
46. Urban, J.; Ingwers, M.; McGuire, M.A.; Teskey, R.O. Stomatal conductance increases with rising temperature. Plant Signal. Behav. 2017, 12, e1356534. [CrossRef]

47. Xu, C.; Mou, B. Drench Application of Fish-derived Protein Hydrolysates Affects Lettuce Growth, Chlorophyll Content, and Gas Exchange. HortTechnology 2017, 27, 539-543. [CrossRef]

48. Xu, C.; Mou, B. Chitosan as Soil Amendment Affects Lettuce Growth, Photochemical Efficiency, and Gas Exchange. HortTechnology 2018, 28, 476-480. [CrossRef]

49. Wozniak, E.; Blaszczak, A.; Wiatrak, P.; Canady, M. Biostimulant mode of action: Impact of biostimulant on cellular level. In the Chemical Biology of Plant Biostimulants; Geelen, D., Xu, L., Eds.; John Wiley \& Sons Ltd.: Hoboken, NJ, USA, 2020; pp. 229-243.

50. Fanasca, S.; Colla, G.; Maiani, G.; Venneria, E.; Rouphael, Y.; Azzini, E.; Saccardo, F. Changes in Antioxidant Content of Tomato Fruits in Response to Cultivar and Nutrient Solution Composition. J. Agric. Food Chem. 2006, 54, 4319-4325. [CrossRef]

51. Bramley, P.M. Regulation of carotenoid formation during tomato fruit ripening and development. J. Exp. Bot. 2002, 53, 2107-2113. [CrossRef]

52. Tzortzakis, N.; Borland, A.M.; Singleton, I.; Barnes, J. Impact of atmospheric ozone-enrichment on quality-related attributes of tomato fruit. Postharvest Biol. Technol. 2007, 45, 317-325. [CrossRef]

53. Guillén, F.; Castillo, S.; Zapata, P.J.; Martínez-Romero, D.; Serrano, M.; Valero, D. Efficacy of 1-MCP treatment in tomato fruit. 1. Duration and concentration of 1-MCP treatment to gain an effective delay of postharvest ripening. Postharvest Biol. Technol. 2007, 43, 23-27. [CrossRef]

Publisher's Note : MDPI stays neutral with regard to jurisdictional claims in published maps and institutional affiliations. 